\title{
Multicriteria Spatial Analysis for Competitive Cultural Heritage in Fringe Areas: the Case of Valle d'Aosta Vastles
}

\author{
Alessandra Oppio ${ }^{1, a}$, Marta Bottero ${ }^{2, b}$ and Valentina Ferretti ${ }^{2, c}$ \\ ${ }^{1}$ Politecnico di Milano, Department of Architecture and Urban Studies, Via Bonardi 3, 20133, Milano, \\ Italy \\ ${ }^{2}$ Politecnico di Torino, Department of Regional and Urban Studies and Planning, Viale Mattioli 39, \\ 10125, Torino, Italy \\ aalessandra.oppio@polimi.it, bmarta.bottero@polito.it, cvalentina.ferretti@polito.it
}

Keywords: Spatial Decision Support Systems, Analytic Network Process, Cultural Heritage.

\begin{abstract}
The Alpine territories show a strong potential in reaching the targets set out by the European policies related to smart, sustainable and inclusive growth. The present paper reflects about the role of cultural heritage in supporting local development processes in mountain areas. In particular, Valle d'Aosta castles' system (Italy) is considered in the study, with particular reference to the analysis of the opportunities and the risks at the regional scale. The results of the work delineate how Multicriteria-Spatial Decision Support Systems (MC-SDSS) can support the definition of enhancement strategies by providing a wide and integrated knowledge of the cultural heritage under investigation. The introduction of MC-SDSS in the field of historical assets' conservation is quite innovative. Differently from the traditional analysis, the use of such an integrated approach allows decision maker to consider the spatial features of each development option and to evaluate simultaneously their multidimensional impacts.
\end{abstract}

\section{Introduction}

A great part of European territory (41,3\% of EU-27) is occupied by mountains, where almost one fourth of Europe's people live [1]. They cover territories with various demographic, social and economic trends, in addition to a great variety of cultures, languages, governance systems and traditions. Along with these differences, the Alpine region shows a territorial variety articulated in five analytical categories: alpine metropolises located at the periphery of the Alps and highly integrated in global economic processes; alpine cities, with large economic attractiveness and quality of life; stable or growing rural areas symbiotic to the larger cities, offering high quality of life and affordable opportunities for the commuting labour forces; declining and shrinking rural areas, that are peripheral areas with low accessibility, hence with little opportunities to connect to the growth poles; touristic areas usually located in the Alps core where tourism is the main economic activity with high seasonal fluctuations [2].

Actually the last three categories play a marginal role, due to development models drawn up elsewhere, incapable of exploiting their specific characteristics and which on the contrary often increase their fragility [3].

Despite the constraints due to the difficult geography, the Alpine territories show a strong potential in reaching the targets set out by the European policies in the current programming period (Horizon 2020). As demonstrated by the priority axes of the ongoing Alpine Space Programme, namely "Innovative Alpine Space", "Low Carbon Alpine Space" and "Liveable Alpine Space", there is an alignment on the following main topics: developing an economy based on knowledge and innovation (Smart growth); promoting a more resource efficient, greener and more competitive economy (Sustainable growth) and fostering a high-employment economy delivering social and territorial cohesion (Inclusive growth). As it emerges from Figure 1, most of the links among EU 2020 targets and Alpine space strategic objectives are focused on the topic of societal challenge. At this level, investing on natural and cultural heritage is a crucial policy measure, since it could be the starting point for new development options balanced with conservation/protection instances $[4,5,6]$. 


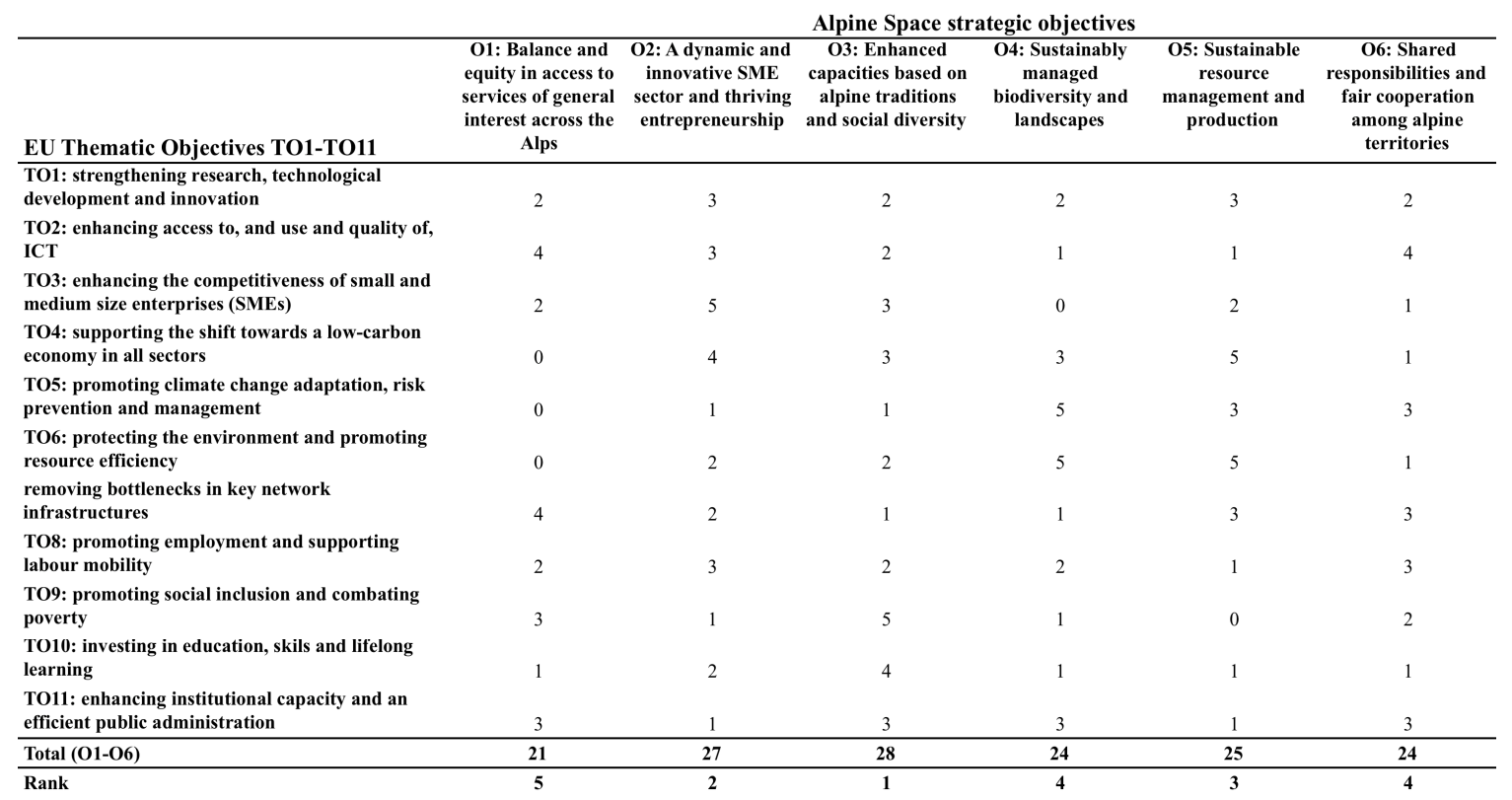

Fig. 1. Cross analysis of Horizon 2020 goals and Alpine Space Programm strategic objectives. The scores from 0 (no clear link) to 5 (core element) are based on a synthesis of positions within a group of experts. Source: Adapted from Gloersen et al., 2013.

Furthermore, in mountain regions enhancing cultural heritage is a crosscutting topic: environmental protection, social and cultural promotion and economic development have the same relevance and there is thus a need to find a durable balance among them. Despite the opportunities of territorial development provided by enhancing cultural heritage $[7,8,9]$, the use of cultural heritage as a mean of tourism development, for example, is not always consensual [10]. Conflicts between preservation of tangible and intangible cultural values for local communities and the heritage marketing according to consumers' needs often arise.

Choices about what and how to conserve for representing us and our past to future generations, therefore, reveal that many different - and sometimes divergent - values (economic, aesthetic, cultural, historical, artistic, educational, political) are subject to discussion. In addition to the presence of different objectives to be pursued, the public/private nature of the goods under investigation involves different actors (public government representatives, architects, architectural historians, developers and owners) directly or indirectly participating in the heritage conservation processes.

Balancing values and preferences of various stakeholders is one of the most difficult challenges in defining conservation strategies.

\section{Supporting the strategies definition process: the methodological framework}

Within this context, a fundamental support may be provided by MC-SDSS [11] which combine Geographic Information Systems and Multicriteria Decision Aiding. MC-SDSS are able to provide a collection of methods and tools for transforming and integrating geographic data (map criteria) and stakeholders' preferences and uncertainties (value judgments) in order to obtain information for decision-making and an overall assessment of the decision alternatives.In recent years there has been a growing interest towards the development and application of MC-SDSS across many scientific fields for solving different decision problem typologies $[12,13]$. The ability of this integrated approach to both generate alternatives during the strategic planning phase and to compare them during the evaluation phase make this tools suitable to deal with complex territorial problems

With specific reference to the planning and decision-making process, the steps needed for the development of an MC-SDSS model are summarized in Figure 2. 


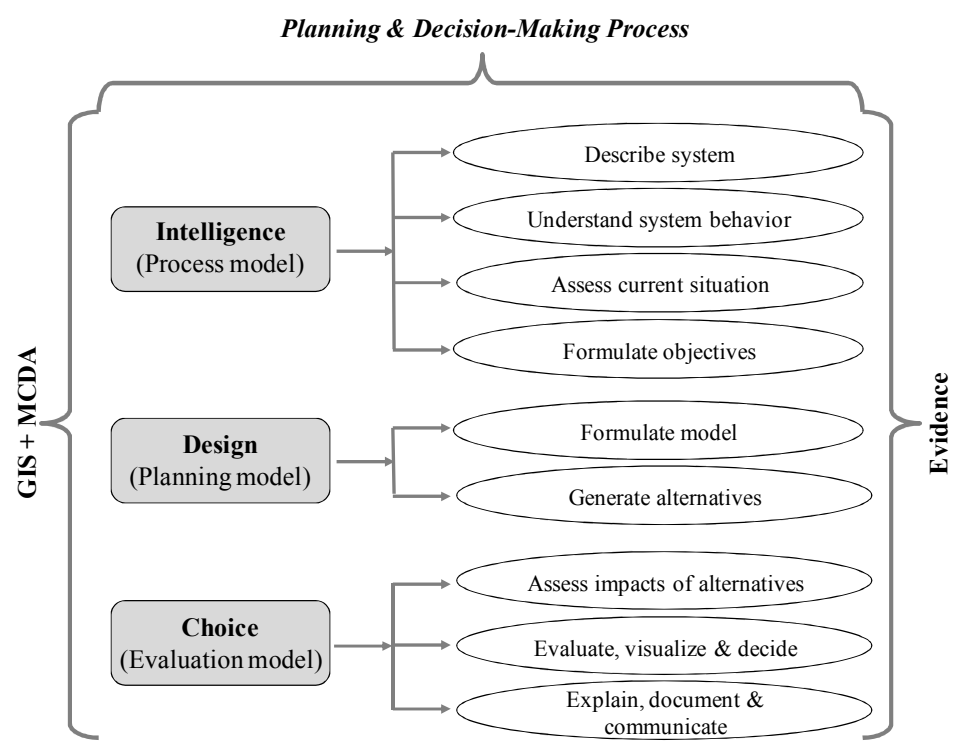

Fig. 2. Framework for planning and decision-making process (Source: adapted from [14].

In particular, the intelligence phase refers to the examination of the environment in order to identify problems or opportunity situations and includes the structuring of the problem, during which the system under consideration is defined and the objectives to pursue are explored. One or more criteria, or attributes, are then selected to describe the degree of achievement of each objective. The design phase involves the development and analysis of possible courses of action. During the choice phase alternatives are evaluated and a selection of specific courses of action is performed; furthermore, detailed analyses, such as the sensitivity analysis, are deemed appropriate in order to obtain useful recommendations. Finally, evidence is defined as the total set of data, information, and knowledge at disposal of the planner, Decision Makers and analysts.

\section{Application}

\section{Presentation of the case and description of the context}

Valle d'Aosta is the smallest Italian region, located in the north-western part of the country and occupying a remarkable mountain area, deeply cut in its middle by the most important infrastructural axis (SS26) and the Dora river. Despite of its size, the Region is characterized by an extremely rich history, represented by the tangible and intangible cultural heritage spread over the region. A significant part of it is made up of castles and fortifications, mostly scattered along the region's central valley, whose impact and visibility is very high although some of them are disused. They have changed their function through the centuries according to different instances: from the need to protect and control territory and communication infrastructures to places of residence. Nowadays the priority is to enhance their role as focal poles of contemporary cultural and long-term socio-economic development of the territory by new uses. In order to face this complex challenge, a MC-SDSS process has been applied to the overall Region for pointing out alternative strategies grounded on the maximisation of the strengths and opportunities given by the cultural goods theirself and by the territorial system.

\section{Model development}

The first step of the analysis consists in structuring the decision problem under examination. In the present case, in order to take into account the complexity of the decision problem under investigation, the Valle D'Aosta castles system was subdivided according to different groups of elements. In particular, the framework proposed by Nijkamp [15] was followed and the main aspects of the problem were organized in several "wares", namely hard-ware (physical infrastructures), eco(environmental impacts), soft- (logistics and informalities), fin- (financial arrangements and funding), org- (institutional and organizational setting), civic (social capital). 
Due to the presence of different interrelated factors, the Analytic Network Process (ANP) method has been applied [16]. The ANP represents the evolution of the Analytic Hierarchy Process (AHP) [17] and it allows to take into account interactions and feedbacks among the decision elements. In the present application, the complex ANP model was developed; in this case, the elements of the problem have been grouped into clusters (represented by the wares) that have been organized according the categories of Opportunities (factors having a positive influence on the problem) and Risks (factors having a negative influence on the problem). The structure of the decision problem under investigation is represented in Table 1.

Table 1 Evaluation model for the Valle d'Aosta castles' system

\begin{tabular}{|c|c|c|c|}
\hline Cluster & Description & Elements & $\mathrm{O} / \mathrm{R}$ \\
\hline \multirow[t]{8}{*}{ Civicware } & \multirow{8}{*}{$\begin{array}{l}\text { Civic-ware deals with the social } \\
\text { capital, it pertains to intra- and } \\
\text { inter-generational equity, } \\
\text { stakeholders and community } \\
\text { involvement, and local quality of } \\
\text { life. }\end{array}$} & Initiative in/about the castle & $\mathrm{O}$ \\
\hline & & Initiative for kids and schools & $\mathrm{O}$ \\
\hline & & Vitality & $\mathrm{O}$ \\
\hline & & Pride of population & $\mathrm{O}$ \\
\hline & & Demographic dynamics & $\mathrm{R}$ \\
\hline & & Permutation rate & $\mathrm{R}$ \\
\hline & & Pour appeal for events & $\mathrm{R}$ \\
\hline & & Tourist/local relationships & $\mathrm{R}$ \\
\hline \multirow[t]{2}{*}{ Software } & \multirow{2}{*}{$\begin{array}{l}\text { Soft-ware is the layer concerning } \\
\text { events and cultural opportunities }\end{array}$} & Distribution of events (based on Summer/Winter database) & $\mathrm{O}$ \\
\hline & & Lack of distribution of events through the year & $\mathrm{R}$ \\
\hline \multirow[t]{6}{*}{ Ecoware } & \multirow{6}{*}{$\begin{array}{l}\text { Eco-ware deals with landscape, } \\
\text { natural resources and natural } \\
\text { environment in general. }\end{array}$} & Mountain dew ponds & $\mathrm{O}$ \\
\hline & & Pathways & $\mathrm{O}$ \\
\hline & & Protected sites & $\mathrm{O}$ \\
\hline & & High quality of agricultural areas & $\mathrm{O}$ \\
\hline & & Vineyards and groves & $\mathrm{O}$ \\
\hline & & Hydrogeological risk & $\mathrm{R}$ \\
\hline \multirow[t]{6}{*}{ Hardware } & \multirow{6}{*}{$\begin{array}{l}\text { Hard-ware describes the physical } \\
\text { territorial characteristics of the } \\
\text { region, concerning accessibility, } \\
\text { mobility and the presence of } \\
\text { services }\end{array}$} & Highways entrances and exits, train stations & $\mathrm{O}$ \\
\hline & & Public transportation & $\mathrm{O}$ \\
\hline & & $\begin{array}{l}\text { Availability of services (hotel, restaurants, post offices, shopping } \\
\text { centers, banks, sports facilities) }\end{array}$ & $\mathrm{O}$ \\
\hline & & Historical pathways & $\mathrm{O}$ \\
\hline & & Historical centers & $\mathrm{O}$ \\
\hline & & Atrophic pressures & $\mathrm{R}$ \\
\hline \multirow[t]{5}{*}{ Org-ware } & \multirow{5}{*}{$\begin{array}{l}\text { Org-ware aims at analysing the } \\
\text { intangible parts of the system related } \\
\text { to the organization, management } \\
\text { and network of relationships }\end{array}$} & Events promoted by municipality departments & $\mathrm{O}$ \\
\hline & & Network density & $\mathrm{O}$ \\
\hline & & Events promoted by external actors & $\mathrm{O}$ \\
\hline & & Hierarchy of relationships among actors & $\mathrm{R}$ \\
\hline & & Number of permanent actors & $\mathrm{R}$ \\
\hline \multirow[t]{2}{*}{ Fin-ware } & \multirow{2}{*}{$\begin{array}{l}\text { Fin-ware describes financial } \\
\text { arrangements and funding. }\end{array}$} & Revenues from tickets & $\mathrm{O}$ \\
\hline & & Income/events ratio & $\mathrm{R}$ \\
\hline
\end{tabular}

In the next phase, the elements have been represented by raster maps where each pixel has a suitability value. The criterion map represents the spatial distribution of the criterion performance in reaching the objective. These maps were derived from basic raster GIS operations (map overlay, buffering, distance mapping, spatial queries, etc.). After criteria identification and mapping, standardization was required to make factors comparable and was performed by using a value function, i.e. a curve that expresses the corresponding value score [18]. This operation converts the source map factor scores into a given value ranging between zero (minimum suitability) and one (maximum suitability) [19].

The next step of the analysis concerned the criteria weighting. A weight was assigned to each criterion to indicate its importance in relation to the other criteria. A specific focus group was organized in order to derive the numerical judgements.

Once the maps were obtained for each criteria and the factor weights were established, it was necessary to combine all the information in order to achieve the overall suitability map. In this case, a weighted linear combination was used, combining the factor maps according to the following formula:

$s_{j}=\sum w_{I} X_{I}$ 
where $S_{j}$ represents the suitability for pixel $j, W_{i}$ represents the weight of factor $i$, and $X_{i}$ represents the standardized criterion score of factor $i$. The factors were combined by applying a weight to each, followed by a summation of the results in order to obtain a suitability map.

\section{Results}

The results of the proposed study are represented by two maps highlighting the spatial distribution of opportunities and risks within the area under examination. These maps represent a first synthesis of negative and positive aspects for each ware obtained through the weighted overlay of all the elements that belong to that specific ware (Figure $3 \mathrm{a}$ and $3 \mathrm{~b}$, respectively).

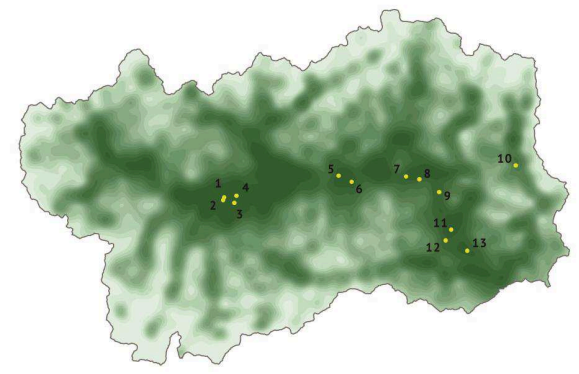

Fig. 3a. Spatial distribution of opportunities

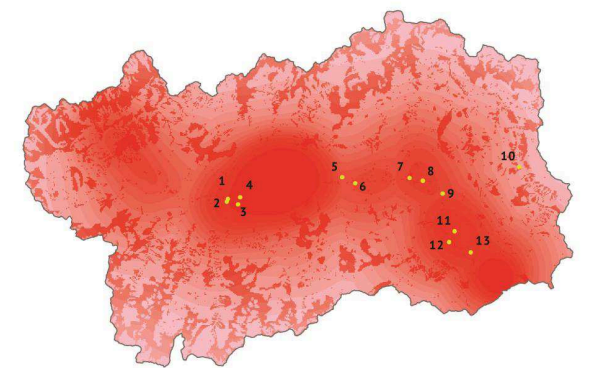

Legend

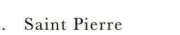

Saint Pierre Aymavilles Sarre Quart Fenis Baron Gamba 3. Ussel 9ontjovet 10. Issogne 11. Verres 2. Arnad
3. Savoia

The analysis of the overall maps displays the existence of a spontaneous organization of clusters of three or four castles which helps to create positive synergies because each castle can benefit from virtuous elements of other castles. In particular, the strongest cluster seems to be the western one, including the castles of Aymaville, Sarre, Saint Pierre and Sarriod de la Tour which is able to share in a good proportion all the existing positive aspects. On the other hand, the negative impacts due to the strong urban pressure exercised by Aosta city and its surroundings (i.e. highway, quarries, landfills) makes the western clusters weaker than the others.

\section{Conclusions}

Although Multicriteria-Spatial Decision Support Systems find few applications in decision processes regarding cultural heritage, this paper suggests that interventions involving this kind of goods as leverage of local development should be addressed by a wide and integrated knowledge about territory. Because of their multifunctional nature, cultural goods call for systemic approaches. Moreover, strategies related to a network of historical assets require to be grounded on the examination of opportunities and risks at a large scale. As it has been shown, MC-SDSS provide a multidimensional framework of analysis, evaluation and definition of future actions according to both tangible and intangible aspects. Furthermore, the maps should be considered as dynamic representation of opportunities and threats to be updated according to the monitoring of territorial systems' change. Finally, such a process shows an high degree of transparency, that is a crucial quality for addressing public policies towards sound decisions.

\section{References}

[1] Information on http://www.euromontana.org/en/themes-de-travail/mountain-2020.html, retrieved on febr. 2014

[2] E. Gloersen, T. Bausch, H. Hurel, W. Pfefferkorn, F. Dal Fiore, C. Ratti, A. Zavodnik-Lamovšek: Strategy Development for the Alpine Space. Final Report, Alpine Space Programme 2014-2020

[3] F. Bigaran, A. Mazzola, A. Stefani: Enhancing territorial capital for developing mountain areas: the example of trentino and its use of medicinal and aromatic plants, Acta geographica Slovenica 53-2, (2013), pp.379-391 
[4] G. Marchesi: Risorse culturali e sviluppo delle aree in ritardo: i fondi strutturali 2000-2006. In: Economia della Cultura, 7(1), (2000), pp. 21-26

[5] S. De Luca, S. Rotondo (Eds.): Le risorse culturali. Studi di fattibilità ed esperienze di gestione, Formez, Rome (2005)

[6] F. Barca: Italia frenata. Paradossi e lezioni della politica per lo sviluppo, Donzelli, Roma (2006)

[7] D. Bayle, M.-S. Humeau: Valoriser le patrimoine de sa commune par le tourisme culturel, Moniteur, Paris (1992)

[8] A. Hausmann: Cultural tourism: marketing challenges and opportunities for German cultural heritage, International Journal of Heritage Studies, 13 (2), (2007), pp. 170-184

[9] L. Sumanov: Cultural heritage and community development, ICOMOS 17th General Assembly, 2011-11-27 / 2011-12-02, Paris

[10] A. Suchet, M. Raspaud: A case of local rejection of a heritage tourism policy: tourism and dynamics of change in Abondance, French Alps, International Journal of Heritage Studies, 16 (6), (2010), pp. 449-463

[11] J. Malczewski: GIS and Multicriteria Decision Analysis, John Wiley \& Sons, New York (1999).

[12] J. Malczewski: GIS-based multicriteria decision analysis: a survey of the literature, Int. J. Geogr. Inf. Sci. 20 (7), (2006), pp. 703-726

[13] V. Ferretti: Le Analisi Multicriteri spaziali a supporto delle procedure di pianificazione e valutazione: analisi e classificazione della letteratura scientifica, Geoingegneria Ambientale e Mineraria, L (2), (2013), pp. 53-66

[14] M.A. Sharifi, E. Rodriguez: Design and development of a planning support sys-tem for policy formulation in water resources rehabilitation: the case of Alcázar De San Juan District in the Aquifer La Mancha Spain, Int. J. Hydroinformatics 4(3), (2002), pp. 157-175

[15] P. Nijkamp, P. Rietveld, H. Voogd: Multicriteria Analysis in Physical Planning, North-Holland Publ. Co., Amsterdam (1989)

[16] T. L. Saaty: Theory and Applications of the Analytic Network Process: Decision Making with Benefits, Opportunities, Costs and Risks, RWS Publications, Pittsburgh (2005)

[17] T. L. Saaty: The Analytic Hierarchy Process, McGraw-Hill, New York (1980)

[18] E. Beinat: Value Functions for Environmental Management, Kluwer Academic Publishers, Dordrecht (1997)

[19] M. Bottero, E. Comino, M. Duriavig, V. Ferretti, S. Pomarico: The application of a Multicriteria Spatial Decision Support System (MCSDSS) for the assessment of biodiversity conservation in the Province of Varese (Italy), Land Use Policy 30, (2013), pp. 730- 738 